\title{
A CASE STUDY WITH SPECIFIC FACTORS MODEL: LABOR-INTENSIVE COMPANIES AT THE EMERGING MARKETS
}

\author{
Ahmet Hakan ÖZKAN \\ Okan University, Turkey
}

\section{ABSTRACT}

Purpose - The entry of the labor-intensive companies to an emerging market causes significant changes like the number of the entering companies, cost of labor, the investments of infrastructure. All these changes constitutes three events of an emerging market: absorption, development and settlement stages. These stages are shown by using a paradigma of specific factors model.

Design/methodology/approach - The datas of Usak and Manisa are elaborated. The collected informations about these two Anatolian cities are evaluated.

Findings - The stages of emerging markets are not only affected by the labor-intensive companies. Some other factors like government incentives are also effective. The stages of the emerging market has a significant affect on the tendency of immigration and the infrastructure investments.

Originality/value - This paper includes a new theory and a new paradigma of specific factors model. International economics is used to define the impacts of a labor-intensive company which enters an emerging market.

Keywords Labor-intensive companies, Paradigma, Specific factors model, Stages of emerging markets.

\section{INTRODUCTION}

The labor-intensive manufacturing industries are generally defined as industries where labor costs are more important than capital costs (Islam and Shazali, 2011). In the labor intensive industries, investment on labor is much more important than the investment on manufacturing machineries. Labor intensive industries usually do not carry high-fixed cost. On the contrary, higher percentage of variable costs is incurred in the labor intensive industries as they use low-tech machineries (Shahidul and Shazali, 2010).

For example, India has been very successful in attracting a large amount of foreign direct investment in recent years. Foreign direct investments into India has grown rapidly since the liberalization of the policy regime in the early 1990s. The World Investment Report (WIR, 2006) has noted that India ranked second as the most attractive investment location in the world, after China (Verma and Brennan, 2011). One of the first entries to the India were the investment of call centers. The call centers did not have a high technology and were labor-intensive.

In China, labor-intensive industries can develope in a short period of time, too. The surveys have shown that there are three stages for a company in China: founding, growth and maturity. At the maturity stage, the Chinese firms tries to be the leader. It is observed that at every event, no labor problem has appeared (Li, Qian and Gaber, 2007). The Chinese answer to the need for trust, legitimation, and ultimately safe market participation was to politically embed private exchange and investment. This constitutes a second building block for securing functioning market places (Krug and Hendrischke, 2010). Firms can reduce their exposure to uncertain enviromental conditions through direct investment in international markets (Kogut, 1983). Consistency on labor is a better alternative of uncertain enviroments. By the way, direct investments to China tended to increase. The political approach of the regional governent has a great affect on the investments.

Local differences within markets have obvious consequences for international business and management research (Bhagat, McDevitt and McDevitt, 2010). Labor-intensive companies can easily adapt the emerging markets in labor-rich countries. For example, India and China are among the world's fastest growing nations and, after Japan, are the largest economies in Asia. From 2007 to 2008, 
China's economic growth rate exceeded 11 per cent while India's growth rate increased to around 9 percent (Chang, 2011). The skill of the workforce is a dominant input of a manufacturing system (Caves, Christensen and Erwin, 1982). Degree of skill is recognized as an effective driving force for enhancing manufacturing performance (Shahidul and Anwar, 2007). It is evident that China and India both have labor with enough skills.

At this study, the entry of labor-intensive companies to an emerging market will be elaborated. Labor will be a constraint. The people with the required qualifications will be accepted as labor. Structural unemployment will be existing. For a better elaboration, a paradigma of Specific Factors Model will be used. Two Turkish cities, Usak and Manisa, are taken as samples and observed. The paradigma is constructed upon the results of these observations.

\section{Paradigma of Specific Factors Model}

The specific factors model leads to increasing opportunity costs because of the law of diminishing returns (Chacholiades, 1990). Specific factors model has three factors of production: labor (L), capital $(\mathrm{K})$ and land ( $\mathrm{T}$ for terrain). Manufacturers can choose to use land or capital, but labor is a must and it is called the mobile factor (Krugman and Obstfeld, 1994).

Paradigma of the specific factors model will be used to elaborate an emerging market where labor is a constraint. The emerging markets with labor constraint have three events: absorption stage, development stage, settlement stage. At the absorption stage, a rush to the emerging market will start. During this rush, the labor of the market will be absorbed by the new companies and the wages will rise. At the development stage new immigrations will come, new investments of infrastructures will be made, suppliers will enter the market. At the settlement stage, the companies will start to use scale economies, some of the existing companies will be eliminated and various new sectors will appear, new investments on education and health will be made.

The three stages of the emerging markets starts with the impact of a factor which encourages the companies to enter the market. This factor is called the trigger factor. This trigger factor can be a government policy, an incentive or a reputable company which enters the market. The trigger factor has to change the expectations of the other companies. The companies with new expectations tends to get a share from the emerging market.

\section{Absorption Stage}

The affects of the new companies entering the market can be seen on Figure I. To show the affects on the labor market we can use a diagram which is similar to the one used by Paul Samuelson and Ronald Jones. The labor-intensive working companies and the other companies will be compared to each other.

Figure 1. Labor Market After New Entries

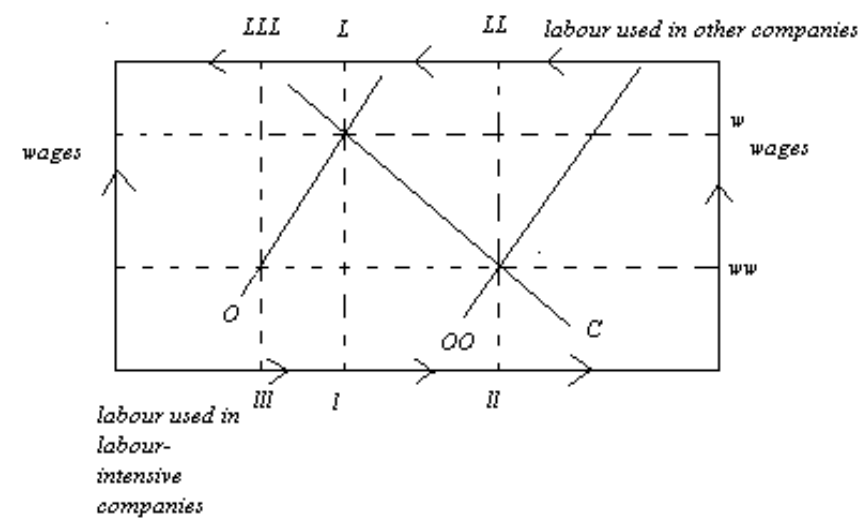

Wages are shown on the lines on the both side. It increases upwards. Labor used in the labor-intensive 
companies is shown on the horizontal line at the bottom. It increases to the right. Labor used in the other companies is shown on the horizontal line at the top and it increases to the left. $\mathrm{C}$ is the labor demand of the labor-intensive companies. $\mathrm{O}$ and $\mathrm{OO}$ are the labor demand of other companies. The point where the labor demand line of labor-intensive companies and the labor demand line of the other companies correspond, is the balance point. As the labor market is closed at this event, the labor supply will be fixed. Thus labor demands will shape the labor market.

The labor market is assumed to be at the balance where $\mathrm{C}$ and $\mathrm{OO}$ corresponds at first. But this balance point will be changed as new companies enter the market. New expectations and "follow the leader affect" will bring some new entries. The labor demand of the other companies excluding the laborintensive ones will increase by the way. New labor demand of the other companies will be like $\mathrm{O}$ and the balance point will be at the intersecting point of $\mathrm{C}$ and $\mathrm{O}$. The new balance point points a higher wage and more labor for the other companies. The wage is the same for all of the companies. But the labor employed changes adversely. As the labor of the other companies increases, the labor of the labor-intensive companies decreases. 1 point shows a lower labor quantity for the labor-intensive companies and a higher labor quantity for the other companies comparing to II. The quantity of the other companies are shown with L and LL. L shows a higher labor quantity comparing to LL.

The reason of assuming the labor market closed is the unability of changing the labor quantity in the short term. In the long term immigrations affect the labor supply and the wages are expected to fall. This expectation of the market can also affect the expectation of the labor-intensive markets. It is mostly observed that labor-intensive companies take action with the expectation of the recent wages to arise again. Therefore the expectations of the labor-intensive companies will give the market a new sight.

The wages of labor-intensive companies are still at the level of ww, but the labor employed quantity is at the level of 11l, instead of I. The reason of trying to keep the wages at the level of ww is the strong belief of the labor-intensive companies in the rigidity of the wages. Rigidity will not let the wages to diminish again and the expectations of the labor will be renovated. Especially the companies with high turnover will be affected more. The employees of these companies will try to move to the other companies due to the changing expectations. At the companies with low turnover, the new employees with higher wages will resist to quit. This will form a dualist structure. This kind of dualist structures are against the principles of the corporational companies. Therefore, the wages of the labor-intensive companies cannot be changed easily.

The new balance point means more labor for the other companies and less labor for the labor-intensive companies. The labor-intensive companies expect the labor market to expand. But as the wages are fixed at ww level, the change at the labor supply is unpredictable. It can be predicted by observing the conditions of the region. If the wages are satisfactory at the region, then new immigrations will come.

The expansion path of a labor-intensive company is shown on Figure 2.

\section{Figure 2. Expansion path of a labor-intensive company}

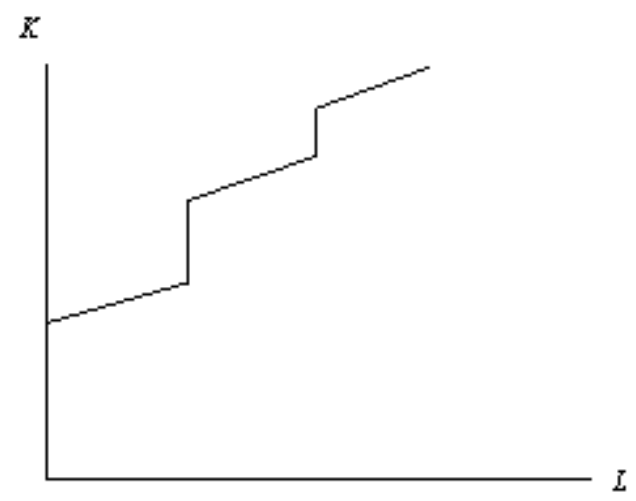

The reasons of the stair like curve can be explained by the dependency of labor employing with the capital. For example, for a call center, a plan and the equipments will be necessary to start the business. 
For this reason the curve starts from the capital line. Any labor employed will bring some extra costs like computer, desk..etc These costs will be met by using capital. So the capital used will increase with the labor used. After a point, there will be no room for a new labor and a new flat or a building will be rent. This new cost will cause a vertical rise on the curve.

This situation and the spreads can be shown by using the classical indifference curves. The indifference curves will look like Figure 3.

\section{Figure 3. Indifference curves of a labor-intensive company}

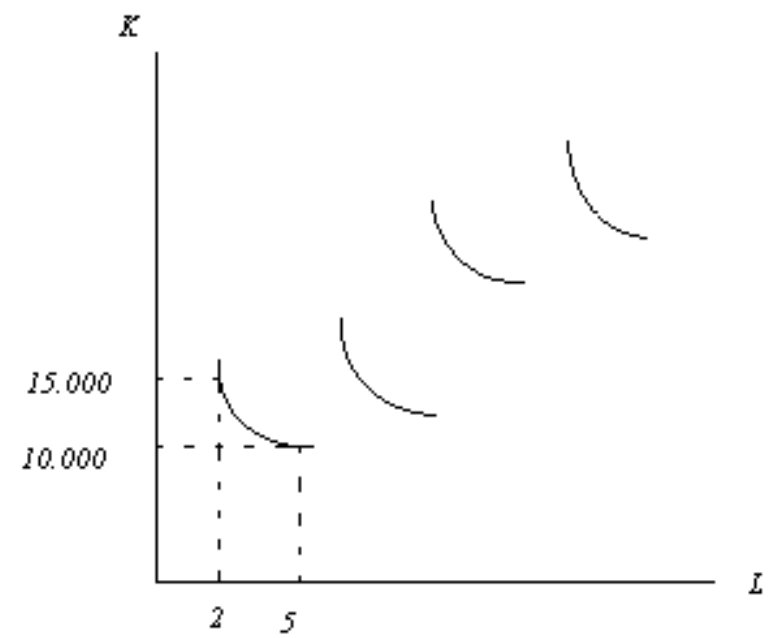

On figure 3, more details can be seen. For example a new plant can be established with $10.000 \mathrm{TL}$ and capacity of 5 people. The plant can start working only by paying at least $10.000 \mathrm{TL}$, and it can start with 5 employees. According to the graphic it can start with 2 people and the work of 3 people can be replaced by paying $5.000 \mathrm{TL}$. This replacements actually does not mean doing the necessary work by making payments. It is the cost of the lacking work of 3 people. The opportunity cost of 3 people is $5.000 \mathrm{TL}$.

The new curves take place at first at the right side and a little bit upper side of the recent one. The spread curves are at the upper side and a little bit right side of the recent one. Each curve shows a different amount of production. The complete graphic is shown on Figure 4.

Figure 4. Expansion path, budget constraint line and indifferences curves of a labor-intensive company

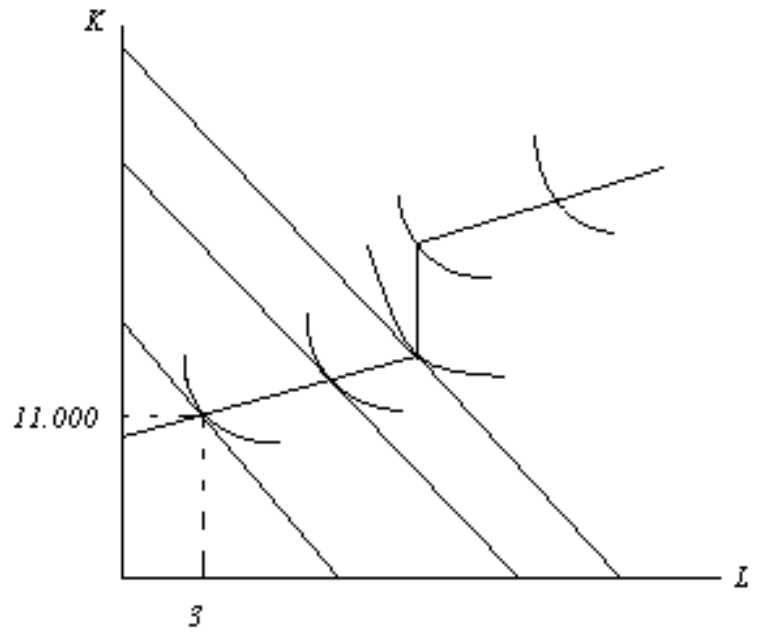


The balance point will be the intersecting point of the budget constraint and the isoquant curves. The new plant will use 3 units of labor and 11.000 units of capital. Because this is the optimum point. The minimum number of the necessary labor is 2 . But employing 1 more labor will diminish the use of capital and 4.000 units will be saved. Employing 2 more labors will bring a saving of 1.000 units. It is not worth employing 2 more labors. The company has to carry the opportunity cost of 1.000 TL if the unit of capital is taken in TL.

The labor cannot be substituted by capital at all of the labor-intensive companies or it is possible to substitute to a certain level. The capital amounts of the isoquant curves just show the opportunity costs of using less labor. There is nothing that capital can buy to replace the labor at the beginning. Labor is the first necessary factor and capital is the second necessary factor. Land is necessay only during the establishment.

\section{Figure 5. Labor demand of the companies}

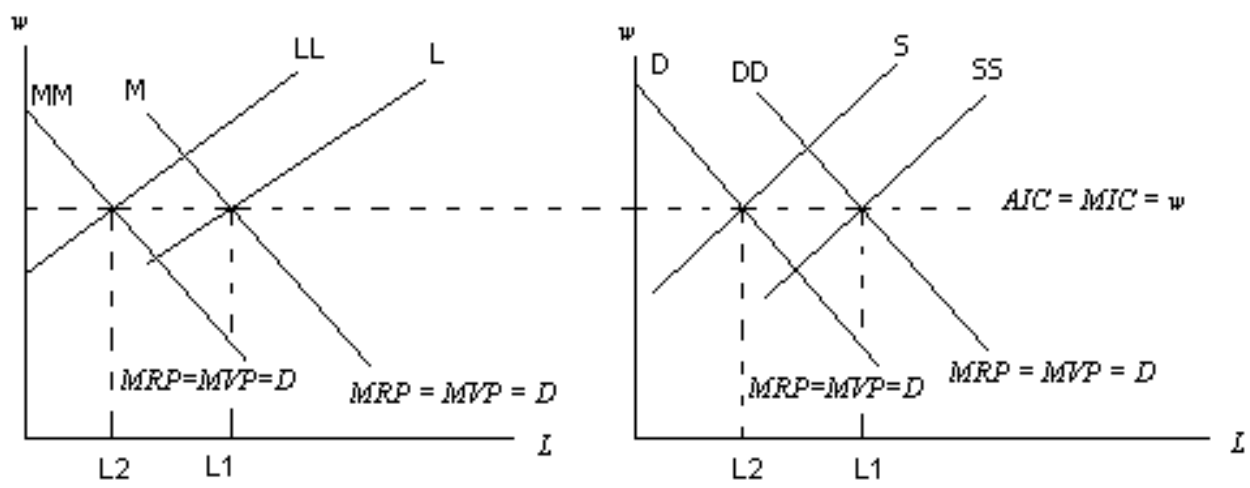

The labor supply and labor demand of the companies are shown on Figure 5. The labor supply and demand balance graphic of the labor-intensive companies is on the left. The labor supply is at first on the line of L. But after the new entries it moves to LL. The employees prefer to work at the other companies instead of the labor-intensive companies at the same level of wages. Because the laborintensive companies requires harder working than the other companies. The labor-intensive companies reduce their labor demand and the demand line moves from $\mathrm{M}$ to $\mathrm{MM}$.

With the new entry of the companies, labor demand of the market will increase. The reduced part of the labor is absorbed by the new companies and they will be increasing their labor quantity to L1. The quantity of the labor will diminish to L2 from L1 at the labor intensive companies. As staying on the L1 point will cause a higher wage, the labor-intensive companies diminish their demand to keep the balance at the same wage level. The first mover companies will try to employ the most qualified labor. But qualifications of the labor is still a constraint.

The amount of labor supply used by the other companies is shown on the right with $\mathrm{S}$ and the demand of labor is shown with D. The labor demand will move to DD and the labor supply will move to DD with the affect of the absorption. Decisively, the labor-intensive companies uses labor at the amount of $\mathrm{L} 2$ and the others use the labor at the amount of L1.

The market, the labor-intensive company started its business in, is actually an emerging market. The other companies require more employees to grow. Emerging markets have low entry barriers and high returns. Therefore more companies will enter the market and the existing companies will keep growing.

The companies which entered the market before the others will have first mover advantages, like the qualified labor. By the way, the first-mover companies will eliminate the new companies. The emerging markets will induce the labor of the small cities to move to the region. The immigration and the exiting companies due to the faster growth of the supply than the demand, will form a new source for the labor-intensive markets. 


\section{Development Stage}

At the development stage, the market will be expanding. The companies will grow and require more labor. The labor will be more and adequate after the immigrations. The infrastructure of the region will also be developed and new investments of the government will be made to keep growing. At this stage, the labor-intensive companies determine the level of the wages and other companies also use the same level.

On Figure 6, the expansion of the market can be realized on both sides. The reason of this expansion is the higher capacity of the labor market due to the immigrations. By the way more labor will be required by both labor-intensive and the other companies. The labor demand of the labor-intensive companies will be higher than the others when the wages are under the required wage level of the labor-intensive companies. Therefore the labor-intensive companies will determine the level of the wages at the required level and keep their labor demand consistent with the labor demand of the other companies.

\section{Figure 6. Labor supply and demand at the development stage}

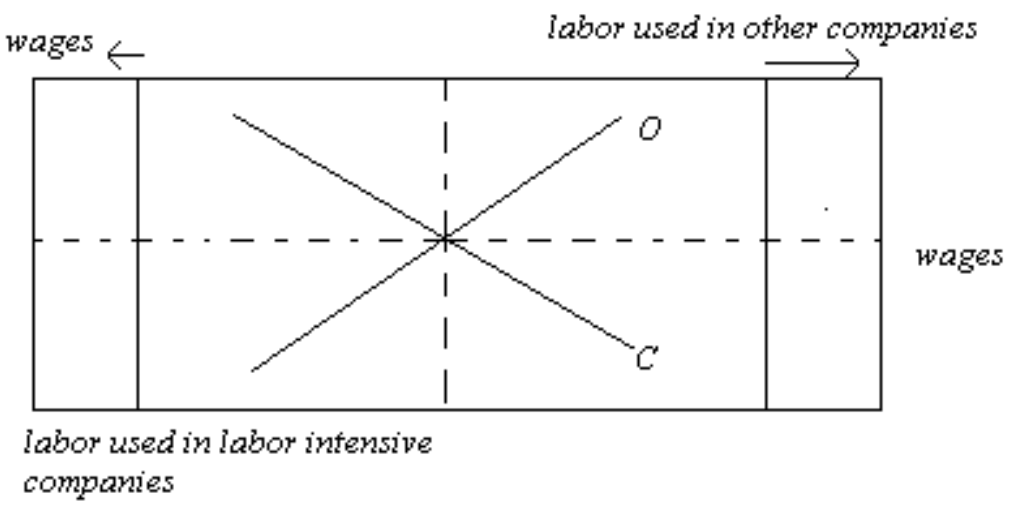

The market will be balanced at the required wage level of the labor-intensive companies. The required wage level is the highest level of the wages which the labor-intensive companies are ready to pay. The labor-intensive companies will not demand more labor after this point.

The companies can employ the labor at the necessary amount by paying the same level of wages as it is seen on Figure 7. This employment level is enough for the labor-intensive companies to maximize their profits. The supply level is fixed at the level of $\mathrm{S}$ which maximizes the profit. The wages are also fixed at the level of w1.

\section{Figure 7. The labor demand of the labor-intensive companies at the settlement}

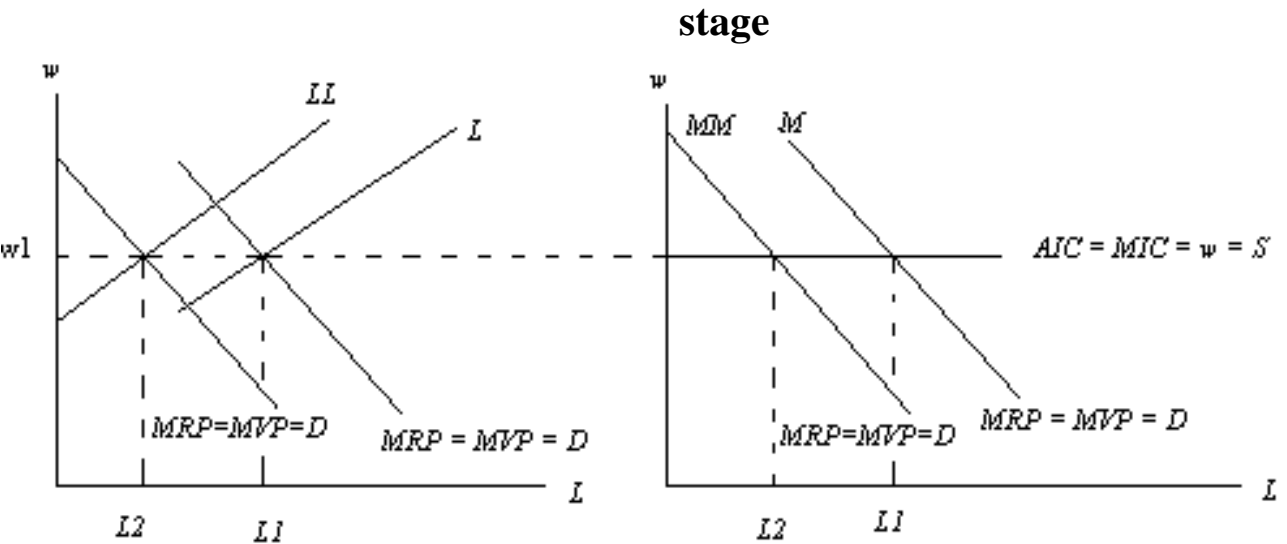

The labor-intensive companies increases their labor demand from LL to L with the increasing labor supply and the quantity of the labor employed will move from L2 to L1. The companies will reach their maximum capacity and the supply level will be equal to $\mathrm{S}$. The labor demand of the labor-intensive companies will be moving from MM to $\mathrm{M}$ and the profit of the corporations will be maximized. The expansion path of the labor-intensive companies will be followed and the companies will start growing. 


\section{Settlement Stage}

The immigrations keep on coming and at the settlement stage there is more labor than necessary. The survivor companies will be eliminating the others and enjoy scale economies. The huge corporations are supported by the government and the infrastructure investments will continue.

\section{Figure 8. The labor balance of the companies at the settlement stage}

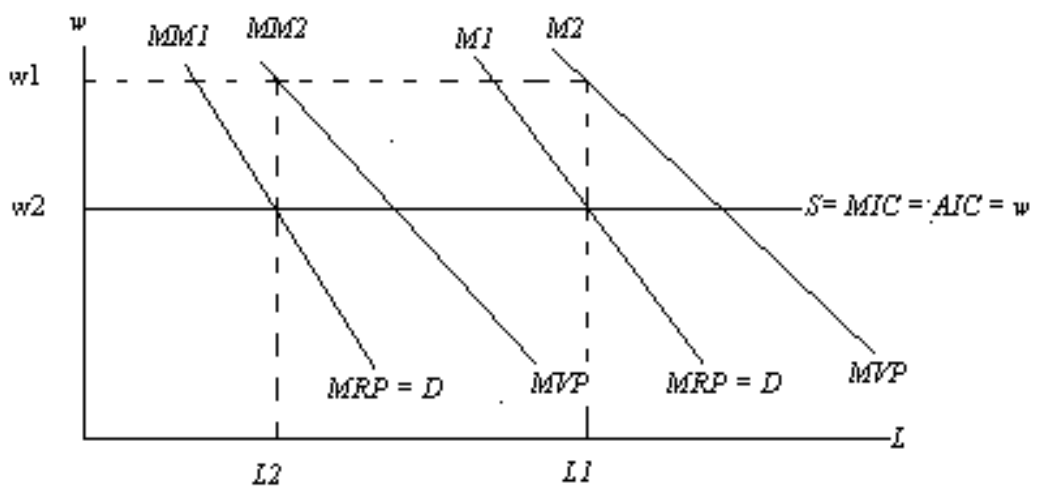

Weak companies exit the market at the settlement stage. By the way the existing companies will receive advantage on employing. With the impact of the scale economies, the survivor companies will be able to gain an extra income which is equal to the difference between w1 and w2. The labor-intensive companies may not be the leader of the sector, but they will be one of the unique employer companies. Thus they will have the power to determine the level of the wages, together with the other significant corporations, and they will prefer the level of w2 instead of w1. The level of w2 is the minimum level which keeps the employees working efficiently.

\section{Evidence from Turkey}

The three stages of the emerging markets are determined by observing Usak and Manisa. Between 2000 and 2009, Usak has passed from absorption stage to development stage and Manisa has passed from development stage to settlement stage.

\section{Table 1. Population Changes of Manisa and Usak}

\begin{tabular}{|c|cc|}
\hline & Manisa & Usak \\
\hline 2000 & 1.260 .169 & 322.313 \\
2008 & 1.316 .750 & 334.111 \\
2009 & 1.331 .957 & 335.860 \\
\hline
\end{tabular}

Source: TUIK, 2009.

As seen on the Table.1, the population of these two cities are tended to increase, even though the population of the cities which are located around these two cities are tended to decrease. Immigration of these cities are seen on Table 2.

Table 2. Immigrations of Manisa and Usak

\begin{tabular}{|c|l|cc|}
2000 & Manisa & Usak \\
\cline { 2 - 2 } & Immigration (number) & 3.687 & -2.058 \\
& Immigration (percent) & 0,321 & $-0,69$ \\
\multirow{2}{*}{2009} & Immigration (number) & -5.481 & -951 \\
\cline { 2 - 2 } & Immigration (percent) & $-0,411$ & $-0,251$ \\
\hline
\end{tabular}

Source: TUIK, 2009. 
The population growth of Manisa is \%11,5 and the population growth of Usak is \%5,2 (TUIK, 2009). Manisa was taking immigration in 2000. In 2009 Manisa started to give immigration. Manisa was at the development stage in 2000 and taking immigrations. In 2009, with the affect of the settlement stage, the opportunity of employment reduced and Manisa started to give immigration. Usak is in transition from absorpment stage to development stage. The immigrations from Usak started to decrease.

The absorption stage of Manisa was before 2000. Vestel was the first company who entered the market in 1984 and it is followed by the other companies. In 2000, Manisa was at the development stage and taking immigrations from the other cities. In 2009, there is more labor than necessary and Manisa is at the settlement stage. The survivor companies are enjoying their scale economies and determining the wages. For example, Vestel is enjoying the scale economies.

The transition of the stages was so fast and effective in Manisa, due to the government incentives. Between 2004 and 2008, 50 entries were enjoying government incentives and Manisa was at the 8th place with the 651.500.000 USD of investment in Turkey. 651.600.000 USD was just the amount of the money invested by these 50 corporations. In 2009, this amount reached 926.924.000 TL with 58 corporations (T.C.Zafer Kalkınma Ajansı and DPT, 2010).

Usak was at the absorption stage in 2000. After the government incentives, some labor-intensive companies are located in Usak. In 2009, 18 entries were enjoying government incentives with 51.080.000 TL. If it is compared to Manisa, after dividing the amount of the investments to the number of the pople employed, the entering companies to Usak are more labor-intensive. Investment per employee is 410.000 TL for Manisa. On the other hand investment per employee is 136.000 TL for Usak (T.C.Zafer Kalkınma Ajans1 and DPT, 2010). The labor-intensive companies prefer Usak. Because it is at the development stage. For example, Metis, which is acquired by Teleperformance, started to operate in Usak. This company focuses on call center services and it is a labor-intensive corporation.

Usak has taken immigration from Afyonkarahisar, Balikesir, Bilecik, Bursa, Denizli, Eskisehir, Konya, Izmir, Isparta, Kutahya, Manisa and Usak between 2008 and 2009. The amount of the immigrations is 4.909 people; 363 people from Afyonkarahisar, 161 people from Balıkesir, 21 people from Bilecik, 171 people from Bursa, 634 people from Denizli, 143 people from Eskisehir, 207 people from Konya, 1.315 people from Izmir, 107 people from Isparta, 784 people from Kutahya, 1.003 people from Manisa (TUIK, 2009).

"BALO" is planned by the Manisa Trade and Industry Chamber. "BALO" is a logistic project which is about the west Anatolian Organisations. Especially a new freight village is planned to be constructed in Usak by the government with the assistment of TCDD, which is an institution of government. Zafer international airport is another project for Usak, Afyonkarahisar and Kutahya (T.C.Zafer Kalkınma Ajans1 and DPT, 2010). 


\section{CONCLUSION}

The political strategies of the governments has a great affect on the investments. In Anatolia, there are some effective government incentives. In 2009, 10 foreign corporations entered to the market of Usak and 65 foreign corporations entered to the market of Manisa. All of these entries were not enjoying the government incentives, but the government incentives encouraged many corporations to enter the market. The investors were expecting better profits from their investments at these cities. As the expectations of the investors were affected, the entries increased.

The specific factors model does not focus on the events. On the other hand, the markets do not change suddenly. The events of the changes must be diversified. The new paradigma, which focuses on the three events of the emerging markets and the labor-intensive companies at these emerging markets, can reflect the results of the events. Besides, the companies are classified like labor-intensive companies and the other companies under the term of labor is a constraint.

The new paradigma may not seem to be valid for Indian and Chinese markets, where labor is not a constraint. Anyway, it is not possible to say that labor is not a constraint in every region of these two countries. It may be better to say, the mobility of the labor is too strong, especially in China, due to the supporting of the government. As a result of this mobility, the transitions between the events of emerging markets may be too fast in these countries. Thus it may be difficult to observe and determine the three stages of emerging markets. 


\section{REFERENCES}

Bhagat, R. S., McDevitt, A. S. and McDevitt, I. (2010) "On improving the robustness of Asian management theories: Theoretical anchors in the era of globalization", Asia Pacific Journal of Management, Vol. 27 No. 2, pp. 179-192.

Caves, D.W., Christensen, L.R. and Erwin, D.W. (1982) "The economic theory of index numbers and the measurement of input, output, and productivity”, Econometrica, Vol. 50 No. 6, pp. 393-414.

Chacholiades, M. (1990) International Economics, McGraw-Hill Publishing Company, Istanbul.

Chang, J. (2011) "The early and rapid internationalization of Asian emerging MNEs", International Business Journal, Vol. 21 No. 2, pp. 171-187.

Islam, S. and Shazali, S.T.S. (2011) "Determinants of manufacturing productivity: pilot study on laborintensive industries", International Journal of Productivity and Performance Management, Vol. 60 No. 6, pp. 567-582.

Kogut, B. (1983), “Foreign direct investment as a sequential process", in Kindleberger, C.P. and Audretsch, D.B. (Eds), The Multinational Corporation in the 1980s, MIT Press, Cambridge, MA.

Krug, B. and Hendrischke, H. (2010) "Market Design in Chinese Market Places", Asia Pacific Journal of Management, www.springerlink.com, 26 August.

Krugnab P.R. and Obstfeld M. (1994) International Economics, Third Edition, Harper Collins College Publishers, New York.

Li, L., Qian, G. and Gaber, B. (2007) "The Chinese enterprise secret: sustained advantage in laborintensive industries”, Journal of Business Strategy, Vol. 28 No. 3, pp. 26-33.

Shahidul, M.I. and Anwar, H. (2007), "Matrix of skill-automation -product cost: few case studies on manufacturing enterprises in Bangladesh", Journal of Arthanity, Vol. 12 No. 1, pp. 150-158.

Shahidul, M.I. and Shazali, S.T.S. (2011) "Dynamics of manufacturing productivity: lesson learnt from labor intensive industries", Journal of Manufacturing Technology Management, Vol. 22 No. 5, pp. 664678

T.C. Zafer Kalkınma Ajansi and T.C. Basbakanlik Devlet Planlama Teskilati (2010) “TR33 Bolgesi, Bolge Planı 2010-2013"

Turkiye Istatistik Kurumu (2009) “TR33 Bölgesi Nüfus Bilgileri”, available at: http://www.tuik.gov.tr/, (accessed 02 February 2011).

Turkiye Istatistik Kurumu (2009) “2000 ve 2009 Yıllarına Ait Net Göç ve Net Göç Hızları”, available at: http://www.tuik.gov.tr/, (accessed 02 February 2011).

Verma, R. And Brennan, L. (2011) “The investment development path theory: evidence from India”, International Journal of Emerging Markets, Vol. 6 No. 1, pp. 74-89.

World Investment Report (2006) FDI from Developing and Transition Economies: Implications for Development, New York, NY. 